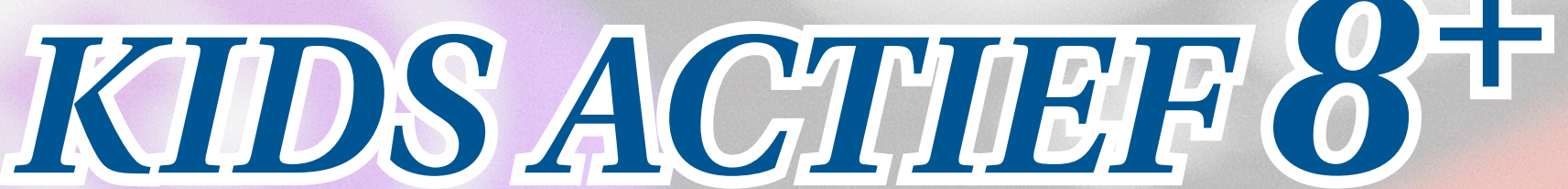

SAMENSTELLING CARLA OVERDUIN

\title{
WORD EEN SOCIAL SMARTIE
}

Social media horen bij het leven van tieners. Zo maak je ze op een creatieve manier mediawijs: maak kaarten in de vorm van een mobieltje, waarop je elke dag een smiley-sticker kunt krijgen. Wie vijf stickers heeft verzameld is een Social Smartie. Zo verdien je een sticker:

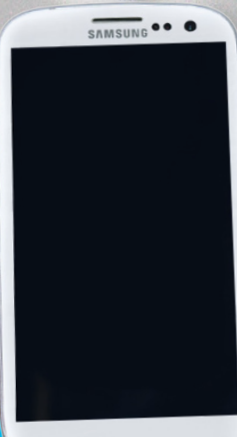

\section{Wijs gebruik}

Experts zeggen dat voor tieners één tot anderhalf uur schermtijd per dag de max is. Maak afspraken, bijvoorbeeld: als je in de bso komt en even wilt Snapchatten, Instagrammen of appen, trek je dan een kwartier terug met je telefoon. Daarna gaat de telefoon weg op een veilige plek en kom je bij de groep.

\section{Pas op met gegevens}

Check met de kinderen: wie heeft zijn adres, e-mail of telefoonnummer op social media staan? Wat moet je nog meer niet doen? Denk aan te blote foto's of foto's waar je later liever niet aan wordt herinnerd.

\section{Ik pest niet}

Cyberpesten is een probleem. Uitschelden via sms, samenspannen in een chat, gemene foto's van elkaar online zetten of zelfs expres een virus sturen via e-mail. Praat er open over met de kinderen. Wie heeft wel eens gepest en wie is slachtoffer geweest? Door ervaringen uit te wisselen, zorg je voor bewustwording. Sluit af met goede afspraken.

\section{ALLEEN VRIENDEN}

Chatten met je vrienden is oké, maar niet met vreemden. Helaas liegen veel mensen op internet. Een volwassene kan een foto van internet pikken, een account aanmaken en net doen of hij ook 10 is. Laat zien hoe makkelijk dit kan. Check met de kinderen: heb je contacten die je nooit echt hebt ontmoet?

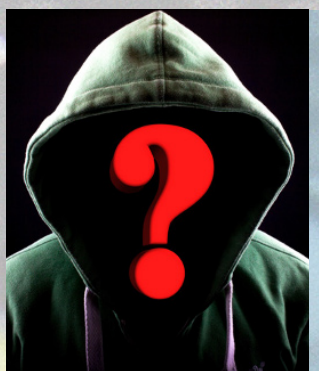

\section{Geen geheimen}

Later mag je natuurlijk doen wat je wilt, maar als je op de bso zit, is je account geen geheim voor je ouders en internetsurfen gebeurt openlijk. De pedagogisch medewerker mag altijd meekijken.

\section{WWWEETJES}

> www.jekindopinternet.nl download de cursus voor online veiligheid voor 7 tot 12 jaar.

> www.halt.nl/veilige-school/sociale-media-en-online-veiligheid Halt geeft les in online veiligheid.

Een van de onderwerpen is digipesten.

$>$ www.veiliginternetten.nl kijk onder de thema's bij 'Kinderen online'.

$>$ www.oudersvannu.nl onder 'Schoolkind' en 'Praktisch en veiligheid' vind je info over veilig internetten. 